\title{
Anatomy in the Third Reich: An Outline, Part 3. The Science and Ethics of Anatomy in National Socialist Germany and Postwar Consequences
}

\author{
S. HILDEBRANDT* \\ Division of Anatomical Sciences, Office of Medical Education, University of Michigan Medical School, \\ Ann Arbor, Michigan
}

\begin{abstract}
Anatomists in National Socialist (NS) Germany did research on materials from animals and humans, including tissues from the bodies of NS victims. The research was competent but rarely innovative. This may be due to the isolation of the German research community from international developments, as well as to the dismissal of a great number of successful anatomists for racial or political reasons. Other research was unproductive because of its foundation in the pseudoscience of racial hygiene. Anatomists in the Third Reich acted according to a new set of medical ethics favored by the NS regime. Not the individual human being but the "body of the people" as a whole was the object of this ethics. Every action was ethical that ensured the health of the German people, including sterilization, so-called euthanasia, and finally mass murder. Anatomists made use of the opportunities given to them by the NS regime, which led to the postmortem utilization of the bodies of NS victims. After the war, most anatomists retained their positions and NS history was not discussed until the later 20th century. Since then, historical research and public discussions have led to an increased awareness of questions of ethics in anatomy. The history of anatomy in the Third Reich illustrates that the theory and practice of a science is dependent on the political system it exists in, and that the scientists' competence not only in their science but also in politics and ethics is a prerequisite for the freedom of science. Clin. Anat. 22:906-915, 2009. @ 2009 Wiley-Liss, Inc.
\end{abstract}

\section{Key words: anatomy; National Socialism; racial hygiene; NS victims; ethics in anatomy}

\section{INTRODUCTION}

Parts 1 and 2 of "Anatomy in the Third Reich" have examined the relationship between politics and anatomy in National Socialist (NS) Germany, the source and identity of bodies for anatomical dissection, their use for other related medical disciplines, and finally the connection between anatomy and racial hygiene. Part 3 analyzes the scientific contributions to the field of anatomy by German anatomists between 1933 and 1945 and the use of bodies of NS victims in their work. The ethics of these anatomists and possible explanations for their behavior will be explored. Lastly, the postwar history of German anatomy is examined. This first overview of the anatomy in the Third Reich shows that much information is available and preliminary conclusions can be drawn, while many questions remain open and require further research.

*Correspondence to: Sabine Hildebrandt, Division of Anatomical Sciences, Office of Medical Education, University of Michigan Medical School, 3767 Medical Science Building II, Catherine Street, Ann Arbor, MI 48109-0608, USA. E-mail: shilde@umich.edu

Received 22 April 2009; Revised 2 September 2009; Accepted 13 September 2009

Published online 16 October 2009 in Wiley InterScience (www. interscience.wiley.com). DOI 10.1002/ca.20874 


\section{METHODS}

Material was collected and analyzed concerning anatomical research in NS Germany, the evaluation of science and anatomy specifically, on the ethics of medicine and anatomists in the Third Reich and the postwar history of anatomy in Germany. To estimate the extent of the use of bodies of NS victims for anatomical research, a sample of 262 papers published in the Zeitschrift für Anatomie und Entwicklungsgeschichte (Anatomy and Embryology) (131 papers) and the Zeitschrift für Zellforschung (Cell and Tissue Research) (131 papers) between 1940 and 1949 was examined. These two journals were chosen because they were commonly used by German anatomists for publication. The time frame includes the war years from 1940, the year with the first significant rise of the numbers of executions, as well as the first postwar years, the latter to estimate the continued use of tissues from the bodies of the executed after the war. The use of the bodies of the executed is taken as an indicator for the general use of bodies of all groups of NS victims (see Part 2) by the respective anatomical department. In addition, anatomical atlases published in the time period were studied.

\section{The Science of Anatomy in National Socialist Germany}

A complete review of anatomical research in Germany during the NS regime has not yet been attempted. The look at a sample of 262 papers shows that German anatomists worked both with animal models and human material on morphological and functional questions of anatomy. The exact provenance of tissues was frequently not listed, but sources of human tissues were given as autopsies, surgical specimens, and executed persons. Most of the studies with listed sources of human tissues in this sample, a total of 15 papers published between 1940 and 1945, reported the use of tissue from the executed (Bauer, 1940; Ferner, 1940; Fleischer, 1940; von Hayek, 1940a,b; Voss, 1940; Bargmann, 1942, 1943; Schreiber, 1942; Hett, 1943; Stöhr, 1943; Ziesche, 1943; Schneider, 1944; Zitzelsperger, 1944; Steege, 1945; Aumüller and Grundmann, 2002).

Some of the "material" from the executed collected until 1945 seems to have been used in research for several years after the end of the Third Reich, without the authors' explicitly naming the source (Graf, 1949; Herrlinger, 1949; Stöhr, 1949; Wallraff, 1949). The terms "died of a sudden death" with "material" removed within 30 min after death (e.g., Wallraff, 1949) or "bodies available directly after death" (e.g., Herrlinger, 1949) are oblique references to the original source of the bodies. In Herrlinger's case, it is documented that he collected "material" directly in the execution chambers at Posen University, where he worked with Hermann Voss (Aly, 1987, 1994). Such tissues could hardly have become newly available to German anatomists after 1945 under the government of the Allied Forces, with the exception of the Soviet occupation zone (David, 2004; p 365). Capital punishment was abolished in the Federal Republic of Germany in 1949.
Studies from outside Germany mention the use of human tissues from the executed only occasionally (Winkelmann and Schagen, 2009). One article in this study's sample stems from Japan, where Seki (1941) reports among other sources of human material the bodies of strangled persons. Theoretically, these could have been suicides, but hanging was also the official method for executions in Japan. Another example comes from Zurich, Switzerland. The use of material from the bodies of two executed persons is mentioned in two publications from this time period (von Möllendorf, 1942; Faller, 1944). As executions were extremely rare in Switzerland at this time, it seems most likely that this research was done on material that originated from Germany, maybe brought with him by von Möllendorf.

Among other anatomists who used "material" from the executed extensively was Hermann Stieve of Berlin. Stieve's field of research was the influence of external factors, including psychological stressors, on the reproductive system. During the 1920 s and 30 s, after preliminary research on animals, he transferred his studies to the human system and observed the effect of acute and chronic nervous anxiety on the reproductive organs from executed males and organs from female accident and suicide victims. The bodies of executed women were extremely rare until the increase of death verdicts and executions under the NS regime. This development gave Stieve the opportunity to study a larger group of female individuals suffering the great acute emotional trauma of being told their date of execution or the loss of menstrual activity due to chronic anxiety. He received clinical data on the women from their prison wardens and was informed about every scheduled execution 2 to 3 days in advance. The bodies were then transported to the anatomical institute and processed there. He published a summary of his research results to international acclaim in 1952 (Stieve, 1952; Aly, 1987; Marx, 2003; p 153-159; Schagen, 2005; Noack, 2007; Winkelmann, 2008; Winkelmann and Schagen, 2009). His institute continued using fresh bodies of the executed during the first years after the war under Soviet occupation (David, 2004; p 365).

Stieve's research belongs to a group of studies that was only possible under the special circumstances of the NS regime, which provided bodies of NS victims in unprecedented quantity and under specific conditions. This research dealt, apart from the effect of great emotional shocks, also with the physical consequences of undergoing prolonged starvation, as seen in Johann Paul Kremer's and Hannes Schneider's studies (Schneider, 1944; Höss et al., 1984)

In addition to this histological research, bodies of NS victims were used in other works, e.g., in the creation of Eduard Pernkopf's "Atlas of Topographical Anatomy" (Williams, 1988).

\section{Preliminary Evaluation of Anatomical Concepts and Research}

German anatomy at the turn of the 19th to the 20th century was concerned with morphology, 
embryology, and comparative anatomy. Especially, the field of Entwicklungsmechanik (experimental and physiological embryology) had proved to be fertile and innovative. However, the emergence of the new dynamic discipline of genetics called for further adaptation and ultimately led to a certain separation of the subdisciplines of embryology and genetics. At the same time, static concepts of morphology were no longer felt to be adequate for modern anatomy. New approaches included a move away from "cadaver anatomy" to an emphasis on functional anatomy and to a holistic anatomical perception of the human being (Rothmaler, 1991; Grundmann and Aumüller, 1996). Hermann Braus was one of the first anatomists who revised the teaching of anatomy by emphasizing not the static morphology but the biological function and interplay of the parts of the body (Schiebler, 1982). His handbook of anatomy moved away from the categories of sets of anatomical systems to a concept that ordered the human body into functional entities (Braus, 1921). Its publication was continued by Curt Elze after Braus' early death in 1924. Braus' anatomy was the first in a series of books and atlases of a dynamic anatomy that was further developed by other anatomists, especially with Alfred Benninghoff's "Functional Anatomy." Other new concepts included a holistic approach to anatomy, as championed by Max Clara and Kurt Alverdes, which focused on the coordinated interaction of individual tissues and organs in the whole body, orchestrated for example by hormones (Clara, 1940; Kühnel, 1989; Rothmaler, 1991; Grundmann and Aumüller, 1996). In the area of anatomical atlases, Eduard Pernkopf's "Atlas of Topographical Anatomy" (Pernkopf, 1943) was also a new development. It showed the most detailed topographical anatomical plates to date reproduced with a new color printing technique, images which even decades later seek their equal in terms of accuracy (Williams, 1988).

Although the conceptual works on dynamic anatomy were in many ways innovative, it has to be noted that much of the research published from 1933 to 1945 was still mostly morphological. Stieve's morphological work was in so far unusual, as it was based on a dynamic theory and postulated changes in the morphology of tissues depending on environmental and psychological influences, a concept distinct from the static ones influenced by racial hygiene (Schagen 2005; Winkelmann and Schagen, 2009). His studies were considered highly relevant by many of his contemporaries, if not by his opponent Hermann Knaus (Marx, 2003; p 153-159; Winkelmann, 2008).

However, the introduction of decisive methodological innovations in anatomy such as the technique of intravital fluorescence microscopy invented by Philipp Ellinger and August Hirt became uncommon in NS Germany. The expulsion or emigration of experienced researchers such as Ellinger, and of young and promising scientists like Ernst A. Scharrer, who went on to develop the new discipline of neuroendocrinology with his wife Bertha in the United States (Bargmann, 1966), is one explanation for the stag- nation in anatomical research in NS Germany. In addition, German researchers became increasingly isolated from their international peers due to the political situation, and German anatomy was cut off from important technological developments in histochemistry and the whole new field of electron microscopy until after the war, even though the latter had been initiated in Germany in the early 1930s (Schiebler, 1982; Kater, 1989; p 239).

Another reason for the lack of development in German anatomy from 1933 to 1945 may have been that a group of anatomists was involved in research in racial hygiene, a field that proved to be unproductive due to its pseudoscientific foundations. Lastly, it has to be considered that during the war years, many anatomists were on active military duty. The colleagues remaining at the universities spent most of their time teaching an ever-increasing number of medical students and had to deal with the physical destruction of their workplace through bombings in the later war years, overall conditions that were not conducive to work based on new ideas.

\section{Ethics of Anatomy in NS Germany}

The question arises why anatomists behaved the way they did in the Third Reich, why they let their colleagues go silently in 1933, why they taught racial hygiene, why they used the multitude of bodies of NS victims for dissection, why two of them were involved in murder. The answer is simple: they thought they were right. In relation to the bodies provided by the government, they were following along the lines of previously established longstanding anatomical laws and traditions in Germany and many other countries that were again reaffirmed by the NS regime (Aumüller, 1991; Hildebrandt, 2008). In relation to racial hygiene, it was accepted scientific knowledge in Germany at the time and informed and justified NS ideology and policies. Racial hygiene also served as the subtext for the dismissal of their colleagues as well as murder of the "unfit." If they had doubts about NS policies, they remained mostly silent (Grundmann and Aumüller, 1996; Holubar, 2000). Many scientists did not believe themselves to be competent in politics and felt responsible only for the freedom of their science (Kühnel, 1989).

Did these anatomists have no ethics? Yes, they did. There were indeed strict ethical standards in NS Germany (Rütten, 1997), and students of medicine studied the subject as part of their mandatory curriculum. Generally, NS medical ideology despised so-called science for science's sake and promoted a medicine that served the German people, the Volk (Proctor, 2000; Hildebrandt, 2006). Thus every action was ethical that ensured the health of the German people as a whole, and such actions included sterilization, so-called euthanasia, and finally mass murder (Kröner, 1996). Traditional medical ethics, in which a doctor's work was focused on the individual patient's benefit, became replaced by a rationality, efficiency, and anti-individualism that ran counter to all previously held values in patientdoctor relationships (Kater, 1989). Not the individual 
human being, but the "body of the people" was the object of NS medical ethics, and human beings were not seen as individuals, but exclusively in their function as parts of the "body of the people." So if this part of the body did not "fit" the general concept of a racially and mentally healthy "body of the people," it had to be either stopped from reproducing or be removed. The question then was no longer whether racial hygienic measures were compatible with the human dignity of the individual, but whether these measures were scientifically up to date and scientifically justified to aid the well-being of the Volk (Weingart et al., 1988, p 320). Individual human beings were stripped of human rights and their bodies, in life and death, became objects of these redefined medical practices (Hommel and Thom, 1989; Thom 1989).

Why were physicians, and in this context: anatomists, so ready to follow the pseudoscientific premises of NS ideology and to give up their traditional ethics? Alexander Mitscherlich suggested that the problem is inherent in any medicine that is exclusively founded in the natural sciences and not also in psychology, and thus might lead over time to a moral dulling of the practitioner of this kind of medicine. He thought that all modern medicine is in danger of drifting into inhumanity by an inevitable process of moral decline inherent in an unchecked purely scientific understanding of medicine (Mitscherlich and Mielke, 1947; p 11/12; Beushausen et al., 1998; p 255/256; Aly, 2005; p 92/93). Likewise, Shevell and Evans state that the dilemma may lie "in the necessary objectivity of the scientific method itself: The need to distance oneself from the experimental subject: Professional distancing begins early in medical training" (quoted from Peiffer, 1997; p 54). Kater referred to this phenomenon, when he called parts of NS medicine an "overextended natural science" representing a "rationality pushed to questionable extremes" (Kater, 1989; p 242).

This rationality of the natural sciences is compounded by the physicians' need to distance themselves from their patients to be an objective observer, diagnostician, and healer. This process was called a "necessary inhumanity" by William Hunter in the 18th century (Richardson, 1987; p 30) and later referred to as clinical detachment. In humane and ethical medicine, clinical detachment is always balanced by empathy (Montross, 2007). In NS medicine, an overreaching clinical detachment combined with a lack of empathy upset this balance, which ultimately lead to monstrosity (a term borrowed from Barker, 1995). Benigna von Schönhagen suggested that anatomists are especially prone to this imbalance, as they may be in greater need of clinical detachment than most other medical disciplines because of the daily necessity of seeing the dead bodies of human beings as "material" and "things" (Schönhagen, 1992). Indeed, this attitude is particularly apparent in Stieve's frequent references to his special "material," tissues from the bodies of young women (e.g., Marx, 2003; p 156; Winkelmann and Schagen, 2009). Peiffer postulates the same inclination to exaggerated clinical detachment for the discipline of psychiatry-neuropathology, in which the practitioner needs a great measure of emotional detachment as self-protection against the mentally diseased patient (Peiffer, 1997). There is a potentially inhuman rationality immanent in a medicine exclusively based on natural sciences and untempered by an ethic that stays focused on the individual patient.

However, it appears that this imbalance is but one factor in the story of medicine and anatomy in the Third Reich. The second factor is the influence and opportunities given by a criminal regime. Proctor stated that "it took a powerful state to unleash the destructive forces within German medicine" (Proctor, 1992). This applies to the science of anatomy, in that the NS regime gave anatomists license to use the new opportunities to their fullest benefit. It also applies to individual anatomists, who were allowed to commit crimes, like Hirt and Kremer (Höss, 1984; p 29), or at least let their own destructive fantasies free reign, as in the example of Hermann Voss (Aly, 1987, 1994). NS policies provided the scientifically interested colleagues "material" in previously unknown quantity and quality, while it offered new opportunities for such politically "adaptable" academics, who might have had little chance for advancement under other political conditions due to their professional character (Peiffer, 1997).

\section{German Anatomy After the War}

After the defeat of NS Germany in May 1945, the occupational forces of the United States, Great Britain, France, and the Soviet Union initiated a denazification process for most of the German population. Every adult German was classified according to his or her involvement in NS political activities as either a "major offender," "offender," "lesser offender," "follower," or "exonerated person." This process included the faculties of all universities. Of the 37 anatomical faculty members who were actively involved in NS politics (see Part 1), two stand out as "major offenders" or "offenders," the war criminals and SS officials August Hirt and Johann Paul Kremer. While Hirt escaped the Nuremberg physician trials by suicide in 1945, Kremer was convicted for murder by the Polish and German governments and spent 10 years in Polish prisons (Landgericht Münster, 1960; Vieten, 1982). Of the remaining 35 NS active anatomists, none are known to have been involved in murder and most of them fell into the categories of "lesser offenders" and "followers." Generally, they were former active SS and SA members and had been vocal in their support of NS politics. Robert Wetzel of Tübingen and Ernst Theodor Nauck of Freiburg had spied on their colleagues for the SS security service (Klee, 2003; Seidler and Leven, 2007; p 482). They lost their appointments after the war, a fate shared by Werner Blume of Göttingen, Eduard Pernkopf of Vienna, Max Clara of Munich, Enno Freerksen of Kiel, and Jürg Mathis and Walter Märk of Innsbruck. Others continued in their academic posi- 
tions directly or after a short hiatus of suspension, e.g., Helmut Becher of Münster, Wilhelm Blotevogel of Breslau, Adolf Dabelow of Leipzig, Anton Kiesselbach of Strassburg, Kurt KF Neubert of Rostock, Klaus Niessing of Kiel, and Gerhard Petry of Halle. The 27 anatomists who had joined an NS affiliation, but had shown no significant political activity, fell into the categories of followers or exonerated persons. Depending on the policies of the occupying forces, some lost their positions for a while, but ultimately all of them held academic appointments in postwar Germany, among them Alfred Benninghoff in Marburg, Ferdinand Wagenseil in Giessen, Maximilian Watzka in the newly refounded medical school of Mainz, and Hermann Voss in Halle and Jena.

Consequently, many, if not the majority, of the anatomical faculty positions in postwar Germany and Austria were filled with persons who had official NS affiliations in their past, as only a minority had never had an NS association. Few of the dismissed anatomists returned after the war, e.g., Karl Saller to Munich, Otto Veit to Cologne, Gustav Sauser to Innsbruck, and Carla Zawisch-Ossenitz to Graz (Ortmann, 1986; Hubenstorf 1988; Beushausen et al., 1998; Oberkofler and Goller, 1999). There are no published postwar statements by the active anatomists during the NS period that refer to their involvement in NS policies and an acknowledgement of responsibility or guilt. When Stieve was questioned about his use of the bodies of executed members of the political opposition for research he said: "the anatomist [...] only tries to retrieve results from those incidents [executions] that belong to the saddest experiences known in the history of mankind. In no way do I need to be ashamed of the fact that I was able to elucidate new data from the bodies of the executed, facts that were unknown before and are now recognized by the whole world" (translation by author, quoted after Schagen, 2005).

Robert Herrlinger, Voss' assistant at the University of Posen, who had worked with fresh tissues harvested in the execution chambers, is most likely an exception among anatomists of this time period, in that he is reported to have regretted his actions later. He, who besides his medical studies was also an art historian, left the field of anatomy and focused on a career in the history of medicine (Aly, 1994; p 152).

Many thousands of medical students had never complained and remained silent about what they had seen in the dissection halls. Their professional socialization included a reality in which great numbers of bodies of those who had suffered a violent death at the hands of a criminal regime were considered the normality. It can only be imagined how these experiences must have influenced these students' future perception of the world in general and their patients in particular. Michael Kater states that "students who had become acculturated to brutalization in the classrooms upon graduation acted out this attitude in daily practice, at the fronts, and, not too few of them, in concentration camps" (Kater, 1989; p 237). Few were later able to admit to feelings of guilt and responsibility as voiced by von Ditfurth (1993; p 168/169) and Bräutigam (1998; p 9).

\section{Postwar Consequences}

As reported in Part 1 of "Anatomy in the Third Reich," the history of anatomy in the Third Reich was generally not talked about in German and Austrian universities until the last decade of the 20th century, when most of the anatomists from this period had retired or passed away. An exception was a short mention of the topic by Wolff-Heidegger and Cetto in their history of artistic depiction of anatomical dissection (1967). On the other hand, the subject was part of several works of fiction over the years (Hochhuth, 1967; Vescovi, 1979; Köhler, 1980; Nalkowska, 2000). A "short history" of the Anatomical Society written by Robert Herrlinger in 1965 gave a summary of some of the research of the time, but did not mention politics or the dismissal of colleagues (Herrlinger, 1965). This finally changed in 1986, when Schierhorn published an article on the fate of the dismissed anatomical colleagues (Schierhorn, 1986), and Kühnel (1989) reported the first 100 years of the society, including comments on the NS period.

For decades after the Second World War, "material" from NS victims was still being used for research, e.g., Spann reports that remains of Austrian resistance fighters were stored at the anatomical institute of Vienna until 1957 (Spann, 1999). Similarly, books authored by NS anatomists were recommended to and read by students of anatomy, without any mention of their origin. Among them were the popular Voss-Herrlinger, a short textbook authored by Hermann Voss and Robert Herrlinger, and Pernkopf's atlas. Results from research from this time period, e.g., Hermann Stieve or Wolfgang Bargmann, were frequently used without the acknowledgment of the origin of their material. The first in-depth discussion about the legitimacy of the use of anatomical work stemming from NS Germany began in the 1980s and focused on Pernkopf's topographical atlas (Hildebrandt, 2006). The Pernkopf controversy was part of a larger discussion concerning the moral legitimacy of using results from NS science (e.g., Caplan, 1992; Michalczyk, 1994).

At this time, the department of anatomy in Tübingen launched an investigation into its NS history and published a comprehensive report in 1990 (Schönhagen, 1992). The report became a model for the Vienna study in 1998, which was prompted by the Pernkopf debate (Malina and Spann, 1999). Since then, documentations have become available from several other institutes (Marburg, Jena, Bonn, Giessen, Göttingen, Halle, Hamburg, Heidelberg). In 2003, the Bundesärztekammer (German medical council) published general recommendations on the treatment of human remains in anatomical collections (Bundesärztekammer, 2003). These were considered necessary because the existence of remaining specimens from NS victims had become widely known (e.g., Rothmaler, 1990). At the same time, a public discussion about the ethics of the treatment of 
human bodies had been sparked by Gunther von Hagens' plastination exhibits in Germany (Hildebrandt, 2008), and laws regulating the handling of materials of questionable ethical background were deemed insufficient. The recommendations include the detailed investigation and removal of specimens of doubtful ethical provenance from collections. Institutes were searched for "material" stemming from the NS period, which included wet specimens and bones, as well as histological slides. The identified items were then removed from the collections and interred in graves of honor; in addition, places of remembrance were created and the public was informed about the process (e.g., Malina and Spann, 1999; Fröber, 2006).

\section{DISCUSSION}

A look at publications from the time period shows that anatomists in NS Germany used the bodies of the executed not only for teaching purposes but also in their research. In terms of the value of this research it can be said that as long as anatomists were concerned with matters of general concepts of anatomy and morphological research, their work showed a certain level of professional competence and often strong engagement (Grundmann and Aumüller, 1996). However, whenever they taught racial hygiene and also pursued research in this discipline, their concepts became compromised by a field that was based on weak scientific evidence as well as ideological stereotypes and conjectures. Mendelian inheritance in race had never been really proven, and the only other methodological approach, twin research, was fraud with its own problems (Kater, 1989; p 227; Mai and van den Bussche, 1989). On the whole, much of the anatomical work during the Third Reich lacked in innovation. The story of the anatomy in the Third Reich demonstrates once more that the biomedical sciences were not destroyed by the National Socialists, but that certain areas were suppressed while others were encouraged (Proctor, 1992; Walker, 2003). Although some of anatomy's theory and practice suffered suppression, namely the dynamic concept of racial hygiene by Saller, most of it was encouraged either by intent of the regime, as in the subject of racial hygiene, or by chance opportunity, as in the availability of a plentiful body supply.

A preliminary answer to the question why the anatomists readily used so many of the bodies of NS victims is complex. As a result of the political situation, the traditional ethics of physicians and academics were newly molded by the ethics of the NS regime. As early as 1938, Hartshorne stated in an analysis of the relationship between German universities and government that civil servants were no longer politically neutral and were held to a political doctrine that mixed scientific fact and fiction (Hartshorne, 1938). The NS regime "unleashed its destructive forces" (Proctor, 1992) on anatomy by first undermining traditional ethical values and then giving legal opportunities for the commitment of crimes and a plentiful body supply. It transformed many anatomists working in NS Germany into opportunistic collaborators of a criminal regime. In terms of the consequences for contemporary anatomy and its ethics, it is most important to look at the science of anatomy and its personnel as a whole. The ethical questions connected with Hermann Stieve's research, a scientist who was not a party member but exploited the bodies of NS victims for his research, have more relevance for modern ethics than those connected with the SS-officers and murderers Hirt and Kremer (Winkelmann, 2008). Indeed, the fact that most anatomists and physicians were not psychopathic criminals, but scientists who thought they were right, is especially disturbing because they were not madmen (Kudlien, 1985; $p$ 197). It also has to be noted that their work was completely legal at the time, even Hirt's and Kremer's "work." However, in the anatomy of the Third Reich, thousands of bodies of NS victims fell prey to a postmortem medical utilization that reached from anatomical institutions to concentration camps (postmortale Verwertungsmedizin: Herber, 1989; Malina and Spann, 1999). Anatomists in NS Germany were part of this process and at least partially responsible for these actions. This responsibility includes the use of bodies of executed NS victims in anatomical research. The neuropathologists showed the same attitude as anatomists, and Peiffer stated that their use of the brains of the euthanasia victims for scientific purposes might have given these killings the appearance of a justified criminal act (Peiffer, 1997; p 51). Indeed, Hallervorden himself compared his work to that of the anatomists and thought it morally correct (Peiffer, 1997; p 52). In the political situation of NS Germany, any preexisting balance between clinical detachment and empathy in these physicians was destroyed. The medical sciences were instrumentalized by the NS regime, and most of the academics working in medicine willingly submitted to this, thereby sacrificing their traditional ethical convictions. The NS medical profession was not without ethics, but had "a lot of bad ethics" (Proctor, 2000; p 342) as seen from a modern point of view.

The question remains whether the anatomists had an alternative and whether they could have realized the point at which their traditional use of the bodies of the executed and the unclaimed became under the NS regime not just quantitatively but also qualitatively different from their work under any other previous government. It seems that at least in the beginnings of the Third Reich, in 1933, academic resistance to the political system was possible within certain limits without dire consequences (Zimmermann, 1991; p 400; Hess, 2005; p 47). One could also change one's field of research, as in the case of Ferdinand Wagenseil, who withdrew from his racial hygienic studies in protest of what he saw as a corruption of the field of racial hygiene by NS ideology (Unger, 1998). In addition, there is one report of a young anatomical researcher, Stieve's assistant Charlotte Pommer, who in December 1942 decided to change her career plans after having had to attend the dissection of an executed woman whom 
she had known personally (Pommer, 1967; Winkelmann and Schagen, 2009). Another option could have been that the anatomists from the very beginning of the NS regime refused to work with the bodies of its victims and use only traditional body sources as previously used. Such a refusal of collaboration could have been successful, as the biologist Alfred Kühn suggested after the war for his own discipline (Peiffer, 2004; p 147/148), and Peiffer did for neuropathology (Peiffer, 1997; p 52). However, the anatomists did not do so, because they saw no ethical problem in their actions. They had lost the ability to "recognize the divine spark and image in every human being" (Cohen and Werner, 2009) and did not or could not see that the medical utilization of victims' bodies was a postmortem humiliation that became part of the victims' biographies (Winkelmann, 2008). These scientists had stopped looking "beyond [their] science" and failed to "examine the circumstances and implications of [their] work" (Cohen and Werner, 2009). They could not see that the theory and practice of their science was entirely dependent on the political system it existed in, and that the scientists' competence not only in their science but also in politics and ethics was a prerequisite for the freedom of science. As a result, they lost this freedom.

Some postwar consequences of the NS period are not yet fathomable. The anatomists' teaching and working at German and Austrian anatomical departments after the Second World War were principally the same as those of the NS period. A handful of very active National Socialists had been dismissed, others, who were initially dismissed in 1945, soon returned to their field of work. Only few of the anatomists expelled in 1933 returned after the war. Thus the anatomy of the 1950s, 60s, and 70s was mostly in the hands of anatomists who had trained and worked in the Third Reich, and as academic teachers they must have impressed their younger colleagues and students with their words and actions (Kater, 1987; p 45). Were they able to change their thinking and their ethics? It is unclear at this point, how and in what manner these men (and very few women) may have shaped the research, teaching, and ethics of postwar German anatomy. If they had a negative influence, this has diminished over time. The discussion and detailed research of the history of anatomy in the Third Reich finally started in the later 20th century, and German anatomy today parallels very much international positive developments of the discipline in terms of the ethical treatment of bodies for dissection. Since the institution of body donation programs in the 1960 s and 1970s, all bodies used for dissection in German anatomical departments are donated bodies, and commemorative services are held to pay respect to the donors. Also, the new generation of German anatomists has shown a heightened ethical awareness in terms of their NS history and lessons to be learned from it (e.g., Aumüller and Grundmann, 2002; Winkelmann and Schagen, 2009).

This first overview of the available literature on the anatomy in the Third Reich shows a complex relationship between anatomists and the ruling NS regime. It was much the same as that of physicists, biologists, chemists, and biochemists, one of compromise and collaboration that ensured the continuity of the individual collaborating scientist's work (Deichmann, 1996; p 327; Deichmann, 2001). Mark Walker summarized: "The German scientific community and most of its members entered a Faustian pact with National Socialism, trading financial and material support, official recognition, and the illusion of professional independence for conscious or unconscious support of NS policies culminating in war, the rape of Europe, and genocide" (Walker, 1995; p 269).

This study also points to areas that still need further research:

- historical investigations of all German or formerly German anatomical institutes, specifically concerning their use of bodies during the NS regime and the political activity of the anatomists,

- identification of all NS victims used in anatomical institutions,

- research into the NS history of other basic medical sciences to compare with the alleged special political activity of anatomists,

- further exploration of the historical relationship between anatomy and physical anthropology, eugenics/racial hygiene, and genetics,

- study of the professional and personal correspondence of anatomists of the NS period to determine any awareness of responsibility and guilt, or lack thereof, concerning their activities during this time,

- research into the possible influence of anatomists of the NS period on postwar anatomical practice and ethics,

- evaluation of the impact of anatomical practices during the NS period on former medical students, and

- exploration of all German archives of governmental and professional Institutions and University Departments of Anatomy and other medical subdisciplines that were involved in the use of human bodies during the time period.

The research so far shows that the story of NS anatomy is one of a medical science that lost its balance between clinical detachment and empathy, and whose ethics and actions became perverted, justified, and instrumentalized by a criminal regime. Depending on the political situation and the ability of psychological and political insight of the individual anatomist, this history has the potential to repeat itself at any time. "Humaneness is not a good that the society or medicine of a certain time period can just claim for itself, but one that has to be permanently worked for to be maintained" [translation by author] (Druml, 1999; see also Horn and Malina, 2002). Thus, all modern anatomists are constantly called upon to evaluate their own balance of clinical detachment and empathy in their daily work with the bodies of humans, and at the same time evaluate their position within the context of their societies. A 
concrete consequence for modern anatomy that can be drawn from the study of this history is the development of ethical standards for the use of human bodies in research and teaching around the world (Hildebrandt, 2008; Winkelmann and Schagen, 2009).

\section{ACKNOWLEDGMENTS}

The author would like to thank the following colleagues for helpful contributions: Gerhard Aumüller, Thomas R. Gest, Robert Jütte, Wolfgang Kühnel, Thorsten Noack, Thomas Waltenbacher, and Andreas Winkelmann. The author specially thanks Stephen Carmichael for excellent editorial guidance.

\section{REFERENCES}

Aly G. 1987. Das Posener Tagebuch des Anatomen Hermann Voss. In: Aly G, Chroust P, Hermann HD, editors. Biedermann und Schreibtischtäter: Materialien zur deutschen Täter-Biographie. Berlin: Rotbuch Verlag. p 15-66.

Aly G. 1994. The Posen diaries of the anatomist Hermann Voss. In: Aly G, Chroust P, Pross C, editors. Cleansing the Fatherland Nazi Medicine and Racial Hygiene. Baltimore: The Johns Hopkins University Press. p 99-155.

Aly G. 2005. Macht-Geist-Wahn. Kontinuitäten deutschen Denkens. Frankfurt am Main: Fischer Taschenbuch Verlag. p 73-93.

Aumüller G. 1991. Die Anatomie in der NS-Zeit. In: Fachschaft Medizin der Philipps-Universität Marburg: "bis der langersehnte Umschwung kam." Von der Verantwortung der Medizin unter dem Nationalsozialismus. Marburg. p 87-112.

Aumüller G, Grundmann K. 2002. Anatomy during the Third ReichThe Institute of Anatomy at the University of Marburg, as an example. Ann Anat 184:295-303.

Bargmann W. 1942. Über Kernsekretion in der Neurohypophyse des Menschen. Z Zellforsch 32:394-400.

Bargmann W, Scheffler A. 1943. Über den Saum des menschlichen Darmepithels. Z Zellforsch 33:5-13.

Bargmann W. 1966. Ernst A. Scharrer zum Gedächtnis. Anat Anz 119:119-127.

Barker P. 1995. The Eye in the Door. Originally published in 1993. London: Plume-Penguin. p 165.

Bauer K. 1940. Über das Grundnetz der menschlichen Grosshirnrinde. $Z$ Zellforsch 30:751-768.

Beushausen U, Dahms H-J, Koch T, Massing A, Ortmann K. 1998. Die medizinische Fakultät im Dritten Reich. In: Becker $H$, Dahms $\mathrm{H}-\mathrm{J}$, Wegeler C, editors. Die Universität Göttingen unter dem Nationalsozialismus. München: K.G. Saur. p 183-286.

Braus H. 1921. Anatomie des Menschen. Ein Lehrbuch für Studierende und Ärzte. Erster Band: Bewegungsapparat. Berlin: Springer Verlag.

Bräutigam H. 1998. Beruf: Frauenarzt. Erfahrungen und Erkenntnisse eines Gynäkologen. Hamburg: Hoffmann und Campe. p 1-255.

Bundesärztekammer. 2003. Arbeitskreis "Menschliche Präparatesammlungen": Empfehlungen zum Umgang mit Präparaten aus menschlichem Gewebe in Sammlungen, Museen und öffentlichen Räumen. Deutsch Ärztebl 8:378-383. English version Available at: http://www.aemhsm.net/ressources/actus/TranslationGuidelines_final.doc [Accessed March 2009].

Caplan AL. (ed.) 1992. "When Medicine Went Mad: Bioethics and the Holocaust". Totowa: Humana Press. p 1-359.

Clara M. 1940. Das Problem der Ganzheit in der modernen Medizin. Leipziger Universitätsreden, Heft 4, Leipzig: Johann Ambrosius Barth Verlag. p 1-44.

Cohen J, Werner RM. 2009. On medical research and human dignity. Clin Anat 22:161-162.
David H. 2004. "... es soll das Haus die Charité heissen...". Band 1. Berlin: Akademos Wissenschaftsverlag. p 1-460.

Deichmann U. 1996. Biologists under Hitler. Cambridge: Harvard University Press. p 1-468.

Deichmann U. 2001. Flüchten, Mitmachen, Vergessen. Chemiker und Biochemiker in der NS-Zeit. Weinheim/New York: WileyVCH. p 1-596.

Druml W. 1999. "Fortschritt kann nur entstehen aus einer umfassenden Präsenz des Vergangenen". Editorial. Wien Klin Wochenschr 111:739-740.

Faller A. 1944. Die Oberflächengestaltung des Epithels in den Ductuli efferentes des menschlichen Nebenhodenkopfes. Z Anat Entw 113:180-186.

Ferner H. 1940. Über den Bau des Ganglion semilunare (Gasseri) und der Trigeminuswurzel des Menschen. Z Anat Entw 110:391404.

Fleischer H. 1940. Über ein regelmässig vorhandenes Ganglion accessorium trigemini und seine Lage im Cavum trigemini. Z Anat Entw 110:755-766.

Fröber R. 2006. Abschlussbericht zur Umsetzung der im Gutachten vom 21. Juni 2005-Prof. Dr. Jütte-ausgewiesenen Empfehlungen über den weiteren Umgang mit den Sammelbeständen am Institut für Anatomie I in Jena. URL: http://www.anatomie1.uniklinikumjena.de/data/anatomie1_/AGFr\%C3\%B6ber/Abschlussbericht.pdf [Accessed April 2009].

Graf P. 1949. Eigenartige Strukturverhältnisse in der Muskulatur der menschlichen Uvula. Z Anat Entw 114:400-419.

Grundmann K, Aumüller G. 1996. Anatomen in der NS-Zeit: Parteigenossen oder Karteigenossen? Das Marburger anatomische Institut im Dritten Reich. Medizinhist J 31:322-357.

Hartshorne EY. 1938. The German Universities and the Government. Ann Am Acad Pol Soc Sci 200:210-234.

Herber F. 1989. Postmortale "Experimentalmedizin" in der Zeit des Faschismus-inwieweit kann der Tod im Dienste des Lebens stehen? In: IPPNW: Das Schicksal der Medizin im Faschismus. Auftrag und Verpflichtung zur Bewahrung von Humanismus und Frieden. Neckarsulm: Jungjohann. p 88-91.

Herrlinger R. 1949. Neue funktionell-histologische Untersuchungen an der menschlichen Milz. Z Anat Entw 114:341-365.

Herrlinger R. 1965. Kurze Geschichte der Anatomischen Gesellschaft. Anat Anz 117:1-60.

Hess V. 2005. "Es hat natürlich alles nur einen Sinn, wenn man sich der Resonanz des Ministeriums sicher ist." Die Medizinische Fakultät im Zeichen der Führeruniversität. In: Jahr Ch, editor. Die Berliner Universität in der NS-Zeit. Band I: Strukturen und Personen. Wiesbaden: Franz Steiner Verlag. p 37-48.

Hett J. 1943. Becherzellpolster in den Speicheldrüsenausfuehrungsgängen (Submandibularis des Menschen). Z Zellforsch 32:335338.

Hildebrandt S. 2006. How the Pernkopf controversy facilitated a historical and ethical analysis of the anatomical sciences in Austria and Germany: A recommendation for the continued use of the Pernkopf atlas. Clin Anat 19:91-100.

Hildebrandt S. 2008. Capital punishment and anatomy: History and ethics of an ongoing association. Clin Anat 21:5-14.

Hochhuth R. 1967. Der Stellvertreter. Originally published in 1963. Reinbeck: Rowohlt. p 1-302.

Holubar K. 2000. The Pernkopf story: The Austrian perspective of 1998,60 years after it all began. Perspect Biol Med 43:382388.

Hommel A, Thom A. 1989. Verbrecherische Experimente in den Konzentrationslagern-Ausdruck des antihumanen Charakters einer der faschistischen Machtpolitik untergeordneten medizinischen Forschung. In: Thom A, Caregorodcev GI, editors. Medizin unterm Hakenkreuz. Berlin: VEB Verlag Volk und Gesundheit. p 383-401.

Horn S, Malina P. (eds.) 2002. Medizin im NationalsozialismusWege der Aufarbeitung. Wien: Verlag der Österreichischen Ärztekammer. p 1-303.

Höss R, Broad P, Kremer JP. 1984. KL Auschwitz seen by the SS Selection, elaboration and notes by Bezwinska, Jadwiga and Czech, Danuta. New York: Howard Fertig. 
Hubenstorf M. 1988. Vertriebene Medizin-Finale des Niedergangs der Wiener Medizinischen Schule? In: Vertriebene Vernunft II: Emigration und Exil östereichischer Wissenschaft. Wien: Verlag Jugend und Volk. p 766-793.

Kater MH. 1987. The burden of the past: Problems of a modern historiography of physicians and medicine in Nazi Germany. Ger Stud Rev 10:31-56.

Kater MH. 1989. Doctors under Hitler. Chapel Hill: The University of North Carolina Press. p 1-426.

Klee E. 2003. Das Personenlexikon zum Dritten Reich. Wer war was vor und nach 1945? Frankfurt am Main: S. Fischer. p 1-731.

Köhler M. 1980. Die Früchte vom Machandelbaum. München: Kindler. p 1-307.

Kröner HP. 1996. Die Umgestaltung der Ethik: Das Los zukünftiger Generationen und die "Volksgemeinschaft". In: Kolb S, editor. Fürsorge oder Vorsorge: Medizin zwischen Patientenwohl and Volksgesundheit. Frankfurt am Main: Fischer Taschenbuchverlag GmbH. p 47-64.

Kudlien F. 1985. Ärzte im Nationalsozialismus. Köln: Kiepenheuer und Witsch. p 1-311.

Kühnel W. 1989. 100 Jahre anatomische Gesellschaft. Verh Anat Ges 82(Anat Anz Suppl 64):31-75.

Landgericht Münster. 1960. Das Urteil gegen Dr. Johann Paul Kremer. In: Justiz und NS-Verbrechen. Band XVII. URL: http:// www1.jur.uva.nl/junsv/Excerpts/Kremer.htm [Accessed September 2006].

Mai C, van den Bussche H. 1989. Die Forschung. In: van den Bussche $\mathrm{H}$, editor. Medizinische Wissenschaft im "Dritten Reich". Kontinuität, Anpassung und Opposition an der Hamburger Medizinischen Fakultät. Berlin/Hamburg: Reimer Verlag. p 165-266.

Malina P, Spann G. 1999. Das Senatsprojekt der Universität Wien "Untersuchungen zur Anatomischen Wissenschaft in Wien 19381945". Wien Klin Wochenschr 111:743-753.

Marx J. 2003. "Der Wille zum Kind" und der Streit um die physiologische Unfruchtbarkeit der Frau. Die Geburt der modernen Reproduktionsmedizin im Kriegsjahr 1942. In: Stingelin M. Biopolitik und Rassismus. Frankfurt am Main: Suhrkamp Verlag. p 112-159.

Michalczyk JJ. (ed.) 1994. Medical Ethics and the Third Reich: Historical and Contemporary Issues. Kansas City: Sheed and Ward. p $1-258$

Mitscherlich A, Mielke F. 1947. Das Diktat der Menschenverachtung. Heidelberg: Verlag Lambert Schneider. p 1-175.

Montross Ch. 2007. Body of Work. Meditations on Mortality from the Human Anatomy Lab. New York: Penguin Press. p 1-296.

Nalkowska Z. 2000. Medallions. Originally published in Polish 1946. Evanston: Northwestern University Press. p 1-49.

Noack T. 2007. Begehrte Leichen. Der Berliner Anatom Hermann Stieve (1886-1952) und die medizinische Verwertung Hingerichteter im Natinoalsozialismus. Med Gesl Gesch 26:9-35.

Oberkofler G, Goller P. (eds.) 1999. Die medizinische Fakultät Innsbruck. Faschistische Realität (1938) und Kontinuität unter postfaschistischen Bedingungen (1945). Eine Dokumentation. Innsbruck. p 1-210.

Ortmann R. 1986. Die jüngere Geschichte des anatomischen Instituts der Universität Köln 1919-1984. Köln: Böhlau Verlag. p $1-136$.

Peiffer J. 1997. Hirnforschung im Zwielicht: Beispiele verführbarer Wissenschaft aus der Zeit des Nationalsozialismus. Husum: Mathiessen Verlag. p 1-112.

Peiffer J. 2004. Hirnforschung in Deutschland 1849-1974. Berlin: Springer Verlag. p 1-1196.

Pernkopf E. 1943. Topographische Anatomie des Menschen. I. Band: Allgemeines, Brust und Brustgliedmasse. Berlin, Wien: Urban und Schwarzenberg. p 1-344.

Pommer Ch. 1967. Letters to Alexandra von Alvensleben [archival source]. In: Archiv des Instituts fur Zeitgeschichte. Munich, Germany: Archive of the Institute for Contemporary History. Document number ED 162.

Proctor RN. 1992. Nazi biomedical policies. In: Caplan AL, editor. "When Medicine Went Mad: Bioethics and the Holocaust". Totowa: Humana Press. p 23-42.
Proctor RN. 2000. Nazi science and Nazi medical ethics: some myths and misconceptions. Perspect Biol Med 43:335-346.

Richardson R. 1987. Death, Dissection and the Destitute. 2nd Ed. (2000). Chicago; London: The University of Chicago Press. p 1453.

Rothmaler Ch. 1990. Gutachten und Dokumentation über das Anatomische Institut des Universitätskrankenhauses Eppendorf der Universität Hamburg 1933-1945. "1999", Zeitschr Sozialgesch des 20. u 21. Jhd 2:78-95.

Rothmaler Ch. 1991. Die Sammlung des Anatomischen Instituts der Hansischen Universität in Hamburg: Didaktisches Konzept und Aufbau 1919 bis 1945. In: Deutsche Gesellschaft für Geschichte der Medizin, Naturwissenschaft und Technik (73 Jahrestagung): Ideologie der Objekte, Objekte der Ideologie; Naturwissenschaft, Medizin und Technik in Museen des 20. Jahrhunderts. Kassel: Georg Wenderoth Verlag. p 55-63.

Rütten T. 1997. Hitler with- or without- Hippocrates? The Hippocratic Oath during the Third Reich. Korot 12:91-106.

Schagen U. 2005. Die Forschung an menschlichen Organen nach "plötzlichem Tod" und der Anatom Hermann Stieve (18861952). In: vom Bruch $R$, Schaarschmidt R, editors. Die Berliner Universität in der NS-Zeit. Band II: Fachbereiche und Fakultäten. Stuttgart: Franz Steiner Verlag Wiesbaden GmbH. p 3554.

Schiebler TH. 1982. Anatomie in Würzburg (von 1593 bis zur Gegenwart). In: Baumgart $P$, editor. Vierhundert Jahre Universität Würzburg: Eine Festschrift. Neustadt and der Aisch: Degener und Co. p 985-1004.

Schierhorn H. 1986. Mitglieder der Anatomischen Gesellschaft im antifaschistischen Exil. Verh Anat Ges 80:957-963.

Schneider H. 1944. Zur Anatomie des Bewegungsapparates. Z Anat Entw 113:187-203.

Schönhagen B. 1992. Das Gräberfeld X auf dem Tübinger Stadtfriedhof. Die verdrängte 'Normalität" nationalsozialistischer Vernichtungspolitik. In: Peiffer J, editor. Menschenverachtung und Opportunismus. Tübingen: Zur Medizin im Dritten Reich. Attempto. p 69-92.

Schreiber H. 1942. Das Muskellager der menschlichen Gallenblasenwand im Vergleich zu der vierfüssiger Säuger. Z Anat Entw 111:91-150.

Seki M. 1941. Retikulumzellen und ihre Abkömmlinge in der Nasenschleimhaut des Menschen. Z Zellforsch 31:203-217.

Seidler E, Leven K-H. 2007. Die Medizinische Fakultät der AlbertsLudwigs-Universität Freiburg im Breisgau. Grundlagen und Entwicklungen. Freiburg: Verlag Karl Alber. p 1-885.

Spann G. 1999. Untersuchungen zur anatomischen Wissenschaft in Wien 1938-1945. Senatsprojekt der Universität Wien. Eine Zusammenfassung (Auszug aus: Dokumentationsarchiv des österreichischen Widerstandes. Jahrbuch 1999). URL: http://www.doew.at/ thema/thema_alt/ns_wissen/medizin/spann.html [Accessed March 2009].

Steege H. 1945. Über den Histotopochemischen Nachweis von Vitamin $C$ in der menschlichen und tierischen Schilddrüse. Z Zellforsch 33:412-423.

Stieve H. 1952. Der Einfluss des Nervensystems auf Bau und Tätigkeit der Geschlechtsorgane des Menschen. Stuttgart: Thieme. p 1-191.

Stöhr P. 1943. Studien zur normalen und pathologischen Histologie vegetativer Ganglien.I. Z Zellforsch 32:587-635.

Stöhr P. 1949. Beobachtungen zur Histopathologie des Muskel- und Nervengewebes im menschlichen Ösophagus. Z Anat Entw 114:185-215.

Thom A. 1989. Die grundlegenden Merkmale der faschistischen Deformierung des humanen Sinnes der Medizin-die Lehren der Geschichte für die soziale Verantwortung des ärztlichen Berufes und die medizinische Ethik in unserer Zeit. In: Thom A, Caregorodcev GI, editors. Medizin unterm Hakenkreuz. Berlin: VEB Verlag Volk und Gesundheit. p 455-465.

Unger M. 1998. Ferdinand Wagenseil (1887-1967). Integrer Forscher und Bewahrer der Medizinischen Fakultät Giessen. Giessen: Wilhelm Schmitz Verlag. p 1-182. 
Vescovi G. 1979. Das Herz sieht anders aus. Stuttgart: Deutsche Verlags-Anstalt. p 1-317.

Vieten B. 1982. Medizinstudenten in Münster. Universität und Studentenschaft 1905-1945. Köln: Pahl-Rugenstein Verlag. p 1-360.

von Ditfurth H. 1993. Innenansichten eines Artgenossen. Meine Bilanz. 3rd Ed. München: Deutscher Taschenbuch Verlag. p 1-431.

von Hayek H. 1940a. Die Läppchen und Septa interlobaria der menschlichen Lunge. Z Anat Entw 110:405-411.

von Hayek H. 1940b. Über die Präkapillaren, die Arteriolen und die Teilungsstellen der kleinen Arterien in der menschlichen Lunge. Z Anat Entw 110:587-596.

von Möllendorf W. 1942. Beiträge zum Verständnis der Lungenkonstruktion. Z Anat Entw 111:224-245.

Voss H. 1940. Vergleichende Histotopochemische Untersuchungen über das Verhalten der Nebenniere zur Plasmalreaktion. Z Zellforsch 31:43-53.

Walker M. 1995. Nazi Science: Myth, Truth, and the Germanic Atomic Bomb. Cambridge: Perseus Publishing. p 1-325.

Walker M. 2003. "Nazi Science"? Natural science in national socialism. In: Hossfeld $U$, John J, Lemuth $O$, Stutz R, editors. "Kämpferische Wissenschaft". Studien zur Universität Jena im Nationalsozialismus. Köln: Böhlau Verlag. p 993-1012.

Wallraff J. 1949. Histochemische Untersuchungen an den Nebennieren des erwachsenen Menschen. Z Zellforsch 34:362-427.
Weingart P, Kroll J, Bayertz K. 1988. Rasse, Blut und Gene. Geschichte der Eugenik und Rassenhygiene in Deutschland. Frankfurt am Main: Suhrkamp. p 1-746.

Williams DJ. 1988. The history of Eduard Pernkopf's Topographische Anatomie des Menschen. J Biocommun 15:2-12.

Winkelmann A. 2008. Wann darf menschliches Material verwendet werden? Der Anatom Hermann Stieve und die Forschung an Leichen Hingerichteter. In: Schleiermacher S, Schagen U, editors. Die Charité im Dritten Reich. Zur Dienstbarkeit medizinischer Wissenschaft im Nationalsozialismus. Paderborn: Ferdinand Schöningh. p 105-120.

Winkelmann A, Schagen U. 2009. Hermann Stieve's clinical-anatomical research on executed women during the "Third Reich". Clin Anat 22:163-171.

Wolf-Heidegger G, Cetto AM. 1967. Die anatomische Sektion in bildlicher Darstellung. Basel, New York: Karger. p 74.

Ziesche KT. 1943. Zur Histologie des Tuber cinereum des Menschen. Z Zellforsch 33:143-150.

Zimmermann V. 1991. Die Medizin in Göttingen während der Nationalsozialistischen Diktatur. Würzburger medizinhistorische Mitteilungen, Band 9. p 393-416.

Zitzelsperger S. 1944. Neue Methoden zur Untersuchung der Reaktionskinetik histologischer Färbungen. Z Anat Entw 113:164173. 